\title{
BRS Esplendor - Common bean cultivar with black grain, upright growth and disease resistance
}

\author{
Joaquim Geraldo Cáprio da Costa $^{1}$, Leonardo Cunha Melo ${ }^{1}$, Helton Santos Pereira ${ }^{1}$, Maria José Del Peloso ${ }^{1}$, Luís Cláudio de Faria ${ }^{1}$, \\ José Luís Cabrera Díaz ${ }^{1}$, Adriane Wendland ${ }^{1}$ and Carlos Augustín Rava (in memorian)
}

Received 2 June 2010

Accepted 5 February 2011

ABSTRACT - BRS Esplendor is a common bean cultivar with black grain, suitable for 12 Brazilian states. The mean productivity is $2,156 \mathrm{~kg} \mathrm{ha}^{-1}$, by $7.5 \%$ higher than of controls, has a high yield potential $\left(4,120 \mathrm{~kg} \mathrm{ha}^{-1}\right)$, upright growth, high tolerance to lodging and high resistance to anthracnose, fusarium wilt and common bacterial blight.

Key words: Phaseolus vulgaris $L .$, grain yield, common bean breeding.

\section{INTRODUCTION}

Brazil is the world's largest producer of common bean, which is the primary protein source in the diet of the Brazilian population. Among the various types of common bean consumed in Brazil, black bean represents about 20 $\%$ of the total production (Del Peloso and Melo 2005), corresponding to about 430,000 tons per year (FEIJÃO 2010). This volume is not sufficient to meet the domestic consumption demand, which is complemented by annual imports of around 100,000 tons. This demand is greatest in the states of Paraná, Santa Catarina, Rio Grande do Sul, Rio de Janeiro and Espírito Santo, although this grain type is sown in other states as well. To supply the demand, the bean is grown all year long, in different tillage systems.

The release of new cultivars has contributed to an increased productivity of common bean in Brazil, with an increase from $749 \mathrm{~kg} \mathrm{ha}^{-1}$ in 1997 to $1,223 \mathrm{~kg} \mathrm{ha}^{-1}$ in 2008 (FEIJÃO 2010). Therefore, the search for new lines with superior phenotypes must be constant.
The common bean breeding program of Embrapa Rice and Beans is focused on the search for cultivars that are more disease-resistant, with high yield and erect plant architecture, enabling a direct mechanical harvesting, so that farmers can offer a better quality product to consumers and earn higher incomes with the crop. Accordingly, new cultivars with excellent plant architecture such as BRS 7762 Supremo (Costa et al. 2006), and BRS Campeiro (Carneiro et al. 2004) with semi-early cycle, have been released in recent years. In this sense, the common bean cultivar BRS Esplendor with black grain is being recommended for planting in Goiás, Distrito Federal, Mato Grosso do Sul, Mato Grosso, Rio Grande do Sul, Paraná, Santa Catarina, São Paulo, Pernambuco, Sergipe, Tocantins, and Rondônia. The cultivar stands out for its upright growth, high yield potential and resistance to nine pathotypes of the causal agent of anthracnose, to bean common mosaic virus-BCMV and moderate resistance to fusarium wilt and bacterial blight.

\footnotetext{
${ }^{1}$ Embrapa Arroz e Feijão, CP 179, 75.375-000, Santo Antônio de Goiás, GO, Brazil. *E-mail: helton@ @npaf.embrapa.br
} 


\section{BREEDING METHODS}

BRS Esplendor was originated from the cross CB911863/AN9123293, performed in 1992 by Embrapa Rice and Beans, in Santo Antônio de Goiás, state of Goiás. From $\mathrm{F}_{2}$ to $\mathrm{F}_{5}$, negative mass selection was performed for anthracnose susceptibility, under field inoculation of alternating pathotypes of Colletotrichum lindemuthianum 89, 89AS, 95, and 453.

In the $\mathrm{F}_{5}$ generation resistant remnants were harvested separately, to establish families in the $\mathrm{F}_{5: 6}$ generation (lines). Line LM 96200768 was evaluated under field conditions, for plant growth type, lodging tolerance, yield and grain type, and was selected for preliminary evaluation tests (PET). In 1999, this line was assessed, along with 127 other lines and four controls in the PET, conducted at four sites (Pelotas - RS, Passo Fundo - RS, Santo Antônio de Goiás - GO, and Ponta Grossa - PR).

In 2001, this line was assessed along with 42 other lines and three controls in the Intermediate test conducted in seven environments: Santo Antônio de Goiás (GO); Ponta Grossa (PR); Lavras (MG); Sete Lagoas (MG); Planaltina (DF); Simão Dias (SE); and Seropédica (RJ). Based on the data analysis of grain yield and other agronomic traits, line LM 96200768, with the provisional name CNFP 8000, was advanced to the Test of Value for Cultivation and Use (VCU).

In the VCU tests, CNFP 8000 was evaluated with 11 lines and 4 controls in 2003 and 2004 in a randomized block design with four replications in four rows of $4 \mathrm{~m}$, using the technologies recommended for various cultivation systems, in a total of 32 environments. Later, in the years 2006, 2007, 2008, and 2009, new VCU tests evaluated the lines in 115 environments. Considering all years, CNFP 8000 was evaluated in 147 environments, in the states of Goiás, Distrito Federal, Mato Grosso, Mato Grosso do Sul, Rio Grande do Sul, Paraná, Santa Catarina, São Paulo, Sergipe, Pernambuco, Tocantins, and Rondônia.

\section{GRAIN YIELD AND PRODUCTION POTENTIAL}

In 147 VCU tests conducted from 2003 to 2009, in the winter growing season in Tocantins, in the rainy growing season in São Paulo, Sergipe, Pernambuco and Rio Grande do Sul, in the dry growing season in Mato Grosso do Sul and Rondônia, in the rainy and dry growing seasons in Santa Catarina and Paraná, in the winter and dry seasons in Mato Grosso and in the rainy, dry and winter seasons in Goiás and Distrito Federal, the grain yield of BRS Esplendor (CNFP 8000) was by $7.5 \%$ higher than the average of the controls IPR Uirapuru, BRS Valente, BRS 7762 Supremo, Guapo Brilhante, and BRS Grafite (Table 1). The overall mean yield was $2,156 \mathrm{~kg} \mathrm{ha}^{-1}$, versus $2,074 \mathrm{~kg} \mathrm{ha}^{-1}$ of the controls. Two controls were always used for comparison and BRS Valente in all tests. IPR Uirapuru was used preferentially as second control, but when not, one of the other varieties mentioned above was used.

Considering the data for each growing season and state, BRS Esplendor performed $29 \%$ better than the controls in the State of Rondônia, in the dry growing season. In Paraná, which accounts for approximately $27 \%$ of the national common bean production, and is therefore the state that produces most grain in Brazil, BRS Esplendor had an average productivity of 2,254 $\mathrm{kg} \mathrm{ha}^{-1}$ and 2,584 $\mathrm{kg} \mathrm{ha}^{-1}$, in the dry and rainy growing seasons, respectively, $22 \%$ and $10 \%$ higher than of the controls, respectively. Also in the states of Sao Paulo and Goiás, which are the second and third largest producers, respectively, the performance of BRS Esplendor was more than $5 \%$ higher than of the controls.

The yield potential of BRS Esplendor, calculated as the average of the five tests in which the cultivar had the highest yields, was $4,129 \mathrm{~kg} \mathrm{ha}^{-1}$. This high value shows that the genetic potential of the cultivar is high and that high yields can be achieved under good cultivation conditions.

\section{OTHER FEATURES}

Regarding the characteristics of industrial and technological grain quality, BRS Esplendor has regular color and grain size and average 100-grain weight of 21.0 grams, slightly lower than that of the controls IPR Uirapuru and BRR Valente (Table 2). The average cooking time of BRS Esplendor is similar to that of the controls, about 31 minutes. The average protein percentage of BRS Esplendor was also similar to the two controls.

Under artificial inoculation, BRS Esplendor is resistant to the bean common mosaic virus and to the pathotypes $23,55,64,71,73,89,97,127$, and 453 of Colletotrichum lindemuthianum, causal agent of anthracnose. In the field tests it was susceptible to angular leaf spot and to bean golden mosaic virus and moderately susceptible to rust, whereas against common leaf blight, anthracnose and fusarium wilt, BRS Esplendor was classified as moderately resistant (Table 3).

With regard to the plant growth type, BRS Esplendor has upright growth and good lodging tolerance and is suitable for mechanical, even direct harvesting. 
JGC Costa et al.

Table 1. Grain yield of cultivar BRS Esplendor compared to the mean of two controls in the test of value for cultivation and use, per state and growing season, between 2003 and 2009

\begin{tabular}{|c|c|c|c|c|c|}
\hline State & Growing season & $\begin{array}{c}\text { BRS Esplendor } \\
\left(\mathrm{kg} \mathrm{ha}^{-1}\right)\end{array}$ & $\begin{array}{c}\text { Control mean } \\
\left(\mathrm{kg} \mathrm{ha}^{-1}\right)\end{array}$ & Relative yield (\%) & $\begin{array}{c}\text { Number of } \\
\text { environments }\end{array}$ \\
\hline \multirow[t]{3}{*}{$\mathrm{GO} / \mathrm{DF}$} & rainy & 2,289 & 2,284 & 100.2 & 13 \\
\hline & winter & 2,666 & 2,473 & 107.8 & 13 \\
\hline & dry & 1,706 & 1,597 & 107.4 & 6 \\
\hline RO & dry & 1,045 & 954,000 & 129.0 & 8 \\
\hline TO & winter & 1,928 & 1,775 & 115.1 & 8 \\
\hline SE & rainy & 2,651 & 2,732 & 97.2 & 9 \\
\hline RS & rainy & 1,844 & 2,188 & 83.8 & 10 \\
\hline PE & rainy & 2,072 & 1,930 & 109.6 & 11 \\
\hline SP & rainy & 2,995 & 2,770 & 112.5 & 5 \\
\hline \multirow[t]{2}{*}{ MT } & dry & 1,488 & 1,391 & 104.5 & 5 \\
\hline & winter & 2,463 & 2,211 & 117.0 & 8 \\
\hline MS & dry & 1848 & 1790,000 & 105.0 & 7 \\
\hline PR & dry & 2,254 & 1,917 & 122.2 & 9 \\
\hline \multirow{3}{*}{$\mathrm{SC}$} & rainy & 2,584 & 2,310 & 110.3 & 7 \\
\hline & dry & 1,658 & 1,520 & 109.1 & 16 \\
\hline & rainy & 2861 & 2899 & 981 & 12 \\
\hline General & & 2,156 & 2,074 & 107.5 & 147 \\
\hline
\end{tabular}

Table 2. Characteristics of grains of common bean cultivar BRS Esplendor, compared to the controls BRS Valente and IPR Uirapuru

\begin{tabular}{lccc}
\hline Cultivar & Cooking time (min.) & Protein content (\%) & 100 grain weight (g) \\
\hline BRS Esplendor & 31 & 18 & 21.0 \\
IPR Uirapuru & 31 & 18 & 23.4 \\
BRS Valente & 31 & 17 & 23.0 \\
\hline
\end{tabular}

Table 3. Agronomic traits and disease reaction of cultivar BRS Esplendor, compared to control BRS Valente

\begin{tabular}{lccccccccccc}
\hline Cultivar & Grain type & Cycle & W100 & PGr & AN & CBB & RU & ALS & BCMV & BGMV & FUW \\
\hline BRS Valente & Black & N & 23 & Upright & MS & S & MS & S & R & S & S \\
BRS Esplendor & Black & N & 21 & Upright & MR & MR & MS & S & R & S & MR
\end{tabular}

N: Normal cycle; W100: 100 grain weight (gram); PGr: Plant growth; AN: Anthracnose; CBB: Common bacterial blight; RU: Rust; ALS: Angular leaf spot; BCMV: Bean common mosaic virus; BGMV: Bean golden mosaic virus; FUW: Fusarium wilt; R: Resistant; MR: Moderately resistant; MS: Moderately susceptible; S: Susceptible.

The cycle of BRS Esplendor is normal (85-90 days from emergence to physiological maturity), similar to the controls. The plants are shrubby, with indeterminate growth habit Type II and the flowers are purple. At physiological maturity, the pods are slightly purplish. At harvest maturity, the pods are bicolored, with light purple streaks on a sand-yellow surface. The beans are black, nearly full elliptical shape, not shiny.

\section{SEED PRODUCTION}

The BRS Esplendor was registered by the Ministry of Agriculture, Livestock and Supply, on 04/29/2008 (nr. 23,105 ). It was also protected, on 12/30/2008 (certificate nr. 20090120). Embrapa Technology Transfer is in charge of the basic seed production of BRS Esplendor.

\section{CONCLUSIONS}

The common bean cultivar BRS Esplendor with black grain has upright plant growth, high yield potential, yield stability, resistance to the major diseases and to lodging.

BRS Esplendor is recommended for cultivation in São Paulo, Pernambuco, Sergipe and Rio Grande do Sul in the rainy, in Tocantins in the winter, in Mato Grosso do Sul and Rondônia in the dry, in Mato Grosso in the winter and dry, in Santa Catarina and Paraná in the rainy and dry and in Goiás in the rainy, dry and winter growing seasons.

\section{ACKNOWLEDGEMENTS}

The authors thank the partner institutions in the cultivar evaluations. 
BRS Esplendor - Common bean cultivar with black grain, upright growth and disease resistance

\section{BRS Esplendor - Cultivar de feijoeiro com grãos pretos, arquitetura ereta e resistência a doenças}

RESUMO - A BRS Esplendor é uma cultivar de feijoeiro comum com grãos pretos, indicada para 12 Estados brasileiros. Apresenta $2.156 \mathrm{~kg} \mathrm{ha}^{-1}$ de produtividade média, 7,5\% de superioridade às testemunhas, alto potencial produtivo $\left(4.120 \mathrm{~kg} \mathrm{ha}^{-1}\right)$, arquitetura ereta, alto nível de tolerância ao acamamento e alta resistência a antracnose, murcha de fusarium e crestamento bacteriano comum.

Palavras-chave: Phaseolus vulgaris L., produção de grãos, melhoramento de feijoeiro comum.

\section{REFERENCES}

Carneiro JES, Faria LC, Pereira PAA, Del Peloso MJ, Rava CA, Costa JGC, Carneiro GES, Soares DM, Díaz, JLC, Melo LC, Mesquita AN, Faria JC, Silva HT, Sartorato A, Bassinello PZ and Zimmermann FJP (2004) 'BRS Campeiro': new black bean cultivar for the South of Brazil. Crop Breeding and Applied Biotechnology 4: 258-260.

Costa JGC, Faria LC, Rava CA, Del Peloso MJ, Melo LC, Díaz JLC, Faria JC, Silva HT, Sartorato A, Bassinello PZ and Zimmermann FJP (2006) BRS 7762 Supremo: a black common bean cultivar with erect plant type recommended for the central west and south Brazil. Crop Breeding and Applied Biotechnology 6: 182-184.
Del Peloso MJ and Melo LC (2005) Potencial de rendimento da cultura do feijoeiro comum. Embrapa Arroz e Feijão, Santo Antônio de Goiás, 131p.

FEIJÃO: dados conjunturais do feijão (área, produção e rendimento) - Brasil - 1985 a 2008. Available at <http:// www.cnpaf.embrapa.br/apps/socioeconomia/index.htm> Assessed on Jan. 7, 2010. 